\title{
Uwarunkowania rozwoju pozarolniczej działalności gospodarczej obszarów wiejskich województwa małopolskiego
}

\author{
Non-agricultural Economic Activity Development \\ of Rural Areas in Małopolska Region
}

\begin{abstract}
Streszczenie: Wpływ działalności rolniczej na kształtowanie struktur funkcjonalnych obszarów wiejskich jest w ostatnich latach coraz mniejszy. Stwarza to nowe uwarunkowania dla rozwoju wsi, zwłaszcza w kontekście ich zwiększającego się potencjału demograficznego. Problem ten jest bardzo ważny z punktu widzenia Małopolski, gdyż województwo to cechuje się bardzo dużym w skali kraju udziałem ludności mieszkającej na obszarach wiejskich. Przekłada się to na bardzo duże rozdrobnienie gospodarstw rolnych i najmniejszą przeciętną ich powierzchnię.

Celem artykułu jest określenie wpływu peryferyjności położenia na rozwój społeczno-gospodarczy obszarów wiejskich województwa małopolskiego. W tekście określono zróżnicowanie dostępności komunikacyjnej regionalnych ośrodków wzrostu na tle poziomu przedsiębiorczości terenów wiejskich.
\end{abstract}

\begin{abstract}
The impact of agricultural activity on the development of structure-functional rural areas has been decreasing in recent years. This creates new conditions for the development of rural areas, especially in light of increasing their demographic potential. This problem is especially important from the point of view of Małopolska province because it has a very large share of the country population living in rural areas. This translates into a huge fragmentation of plots and the smallest average area of the farms. The aim of this article is to determine the effect of peripheral location on socio-economic development of rural areas of the province. The paper also identified the accessibility to regional growth centers on the background of the level of entrepreneurship in rural areas.
\end{abstract}

Słowa kluczowe: dostępność komunikacyjna; Małopolska; obszary wiejskie; rozwój lokalny; rozwój regionalny; województwo małopolskie

Key words: accessibility; local development; Małopolska region; regional development; rural areas

\section{WSTĘP}

Transformacja ustrojowa i związana z nią restrukturyzacja gospodarcza skutkują zmniejszeniem się znaczenia sektora rolniczego i przemysłowego w aktywizacji zasobów pracy. Rozwój sektora usług ma natomiast miejsce głównie na obszarach miejskich. Obszary 
wiejskie są pod tym względem w gorszej sytuacji. Należy więc postawić pytanie o możliwe ścieżki rozwoju tych obszarów. Problem ten jest szczególnie istotny na obszarze Małopolski, która charakteryzuje się bardzo dużym w skali kraju udziałem ludności mieszkającej w gospodarstwach domowych posiadających ziemię, ogromnym rozdrobnieniem działek rolnych i zarazem najmniejszą przeciętną powierzchnią gospodarstw rolnych. Skutkuje to bardzo wysokim odsetkiem ludności powiązanej z rolnictwem, która m.in. dzięki unijnym dopłatom zamieszkuje gospodarstwa rolne mające charakter socjalny, a nie produkcyjny (Górz, Uliszak, 2009).

Ważnym elementem wyjaśniającym zróżnicowanie przestrzenne rozwoju obszarów wiejskich w układzie regionalnym na osi miasto (metropolia) - wieś jest kwestia dostępności przestrzennej. Dostępność przestrzenna najczęściej definiowana jest jako łatwość osiągnięcia określonej lokalizacji z innych miejsc (Guzik, 2003). Nie istnieje ona jako cecha miejsca sama w sobie - zawsze musi być określona przez wskazanie miejsc, w stosunku do których jest mierzona, użytkowników tej dostępności oraz środków, jakimi pokonywana jest przestrzeń (Nutley, 1983). Dostępność można mierzyć odległością, czasem lub/i kosztem pokonania przestrzeni (Pacione, 1989). W przeprowadzonych badaniach miernikiem dostępności był czas dojazdu do Krakowa i ośrodków subregionalnych z całego terenu województwa małopolskiego.

W obecnych czasach, kiedy działalność usługowa i produkcyjna cechuje się koncentracją w dużych zespołach miejskich, dostępność do tego typu ośrodków jest kluczowa z punktu widzenia rozwoju poszczególnych regionów (Nutley, 1998). Dostępność ma wpływ na szereg sfer, m.in. poziom i jakość życia czy atrakcyjność inwestycyjną, jest istotnym elementem organizacji przestrzeni znajdującym odzwierciedlenie w zróżnicowaniu atrakcyjności poszczególnych miejsc, szczególnie w zakresie rynku pracy (Komornicki i in., 2010; Guzik, Wiedermann, 2012). Coraz częściej pojęcie dostępności przestrzennej staje się częścią wykorzystywanej politycznie retoryki sprawiedliwości społecznej, walki z wykluczeniem społecznym czy zapewniania równości szans (Keeling, 2009). Podkreśla się, że dostępność do urządzeń infrastruktury społecznej, a szczególnie do placówek edukacyjnych i służby zdrowia oraz do miejsc pracy jest wyznacznikiem szans życiowych (Moseley, 1979; Pacione, 1989; Farrington i Farrington, 2005; Taylor, 1998). Z kolei słaba dostępność do kluczowych usług oraz miejsc pracy jest jednym z wymiarów wykluczenia społecznego (Farrington, 2007) i coraz częściej jest przedmiotem analiz z perspektywy sprawiedliwości społecznej.

Celem opracowania jest wskazanie kierunków zachodzących obecnie zmian, zarówno pod względem strukturalnym, jak i przestrzennym. W tym celu opisano współczesne zróżnicowanie procesów ekonomicznych na terenie województwa małopolskiego i przedstawiono wstępną prognozę dalszych zmian. W niniejszym opracowaniu przedstawiono także zależności pomiędzy dostępnością komunikacyjną obszarów wiejskich do głównych ośrodków stanowiących najważniejsze centra wzrostu w województwie małopolskim a poziomem aktywności ekonomicznej na tych terenach. Wykazano zależności wynikające z dostępności transportowej i aktywizacji regionów wiejskich. 
Sytuacja SPOŁECZNO-GOSPODARCZA TERENÓW WIEJSKICH MaŁOPOLSKI

Pozarolnicza działalność gospodarcza może być szansą na zwiększenie poziomu dochodów ludności rolniczej. W obecnej sytuacji społeczno-ekonomicznej rolnictwo przestało być najważniejszym źródłem dochodów na wsi. Wieś już nie może być utożsamiana z rolnictwem.

Według Raportu (Polska wieś..., 2012), około 40\% gmin wiejskich Małopolski, znajdujących się przede wszystkim w strefie Krakowskiego Obszaru Metropolitalnego i otoczeniu innych większych miast regionu, cechowało się korzystnymi wskaźnikami dezagraryzacji. Możemy w tych przypadkach wskazać na znaczne zróżnicowanie funkcji, wysokie wskaźniki zatrudnienia pozarolniczego i dochodów czerpanych z pracy pozarolniczej. Stale zmniejsza się powierzchnia gruntów rolnych w Małopolsce. Pomiędzy rokiem 2002 a 2010 ich obszar zredukowany został o ponad 13,3\% (Raport z wyników..., 2011). Według danych z obecnego spisu rolnego z 2010 r. w ciągu ośmiu lat w Małopolsce ubyło 24,1\% gospodarstw rolnych, ale wciąż pozostaje województwem o największej ich liczbie w kraju. Wyniki Spisu Rolnego 2010 świadczą o tym, że wiele gospodarstw rolnych w Małopolsce nie zajmuje się produkcją rolniczą. Stanowią one ponad $20 \%$ ogółu gospodarstw.

Jednocześnie polskie rolnictwo gospodaruje w warunkach europejskiego obszaru gospodarczego, na terenie którego od kilkudziesięciu lat występuje nadprodukcja niektórych płodów rolnych. Wiele z nich (np. pszenica, mleko i nabiał) należały do podstawowej produkcji omawianego regionu. W warunkach otwarcia polskiego rynku od początku lat dziewięćdziesiątych XX wieku na silnie dotowane produkty rolnicze pochodzące z krajów „starej” Unii Europejskiej rolnicy z Małopolski stanęli w obliczu kurczącego się rynku zbytu. W momencie otwarcia polskiego rynku na produkty unijne dopłaty w ramach Wspólnej Polityki Rolnej kierowane były głównie na konkretne surowce pochodzenia rolniczego. Sprzyjało to zwiększaniu produkcji w krajach „starej” Unii i konkurencyjności produktów importowanych do krajów kandydujących (w tym Polski). Sytuacja uległa diametralnej zmianie wraz z reformą WPR i przystąpieniem naszego kraju do Unii. Przykładowo w roku 1991 niespełna $30 \%$ budżetu WPR stanowiły subsydia eksportowe, ok. 7\% fundusze wspierające rozwój terenów wiejskich, a około $2 / 3$ było przeznaczone na wsparcie produkcji rolnej. W roku 2006 było to odpowiednio 5\%, ponad 20 i ok. 10\%. Pozostała część budżetu przeznaczona została na dopłaty do produkcji i uproszczone bezpośrednie, czyli obszarowe, które nie są związane z kierunkiem produkcji (European Commission, 2011). Te ostatnie odnoszą się do użytków rolnych w Polsce. Taka sytuacja sprzyja utrzymywaniu ziemi rolniczej nawet bez podejmowania żadnej produkcji rynkowej.

Małopolska należy do regionów o dużym potencjale demograficznym głównie na terenach wiejskich. O jej wiejskim charakterze świadczy m.in. mniejszy niż średnio w Polsce wskaźnik urbanizacji. Dodatkowo liczba osób mieszkających w miastach maleje w ostatnich latach (Kwiatek-Sołtys 2011). Na małopolskiej wsi zamieszkuje wciąż (2011 rok) większa część populacji regionu - nieco poniżej 51\% (Raport z wyników..., 2012). W okresie między ostatnimi dwoma spisami powszechnymi (tzn. 2002 i 2011) liczba ludności województwa 
zwiększyła się, ale był to głównie przyrost ludności wiejskiej (o prawie 6\%). Zmiana ta jest różna od procesów demograficznych zachodzących w innych regionach kraju. Dynamika wzrostu liczby ludności wiejskiej w okresach międzyspisowych należy obecnie do największych w powojennej historii. Porównywalna dynamika (wynikająca głównie z przyrostu naturalnego) miała miejsce w dekadzie lat pięćdziesiątych i w latach 1978-1984. Małopolska wieś tradycyjnie charakteryzuje się stosunkowo wysokim przyrostem naturalnym. Dotyczy to głównie terenów podgórskich i górskich położonych w południowej części regionu (np. dawne województwo nowosądeckie oraz tarnowskie). Równolegle następuje wzrost udziału procentowego osób mieszkających na wsi, a to już jest zjawisko nieobserwowane dotychczas w powojennej historii. Proces ten wynika zarówno z bardzo niskiego lub wręcz ujemnego przyrostu naturalnego w miastach, jak i trwałego ujemnego salda migracji w tych jednostkach osadniczych.

Podobne procesy ludnościowe można zaobserwować w większości polskich miast. Trochę różnią się one od tych zachodzących w największych ośrodkach pełniących głównie funkcje centralne najwyższego szczebla. W przypadku Małopolski drugi pod względem liczebności w Polsce ośrodek miejski Krakowa jest silnym magnesem regularnie przyciągającym migrantów (ryc. 1). O jego sile świadczy m.in. fakt, że wciąż skupia prawie 23\% mieszkańców województwa, choć oficjalnie jego zaludnienie w ostatnim okresie między spisami powszechnymi zmniejszyło się o niecały tysiąc osób. Stało się tak głównie na rzecz otaczających miasto gmin powiatu krakowskiego ziemskiego i wielickiego. Ruch ten jest typowym przykładem procesów suburbanizacyjnych. Ludność migrująca na obszary podmiejskie cechuje się np. wyższymi wskaźnikami wykształcenia oraz całkowicie pozarolniczymi źródłami utrzymania (Borowiec, 2008).

Z opracowanej typologii zmian demograficznych gmin Małopolski w latach 20022004 i 2009-2011 wynika, że obszar Krakowa oraz otaczających go gmin cechuje się dodatnim saldem migracji, przeważającym nad przyrostem naturalnym (typy $\mathrm{C}$ oraz $\mathrm{D}$ na ryc. 1). W tym kontekście wyraźnie zaznacza się oddzielność Krakowskiego Obszaru Metropolitalnego (KOM) od reszty województwa. Środkowa i południowa część Małopolski charakteryzuje się również dodatnimi zmianami liczby ludności wiejskiej, ale na tych terenach tradycyjnie najważniejszą rolę odgrywa przyrost naturalny (typy C oraz D na ryc. 1). Nowym zjawiskiem (ryc. 1) jest poprawiająca się sytuacja demograficzna niektórych gmin położonych na północ i północny zachód od Krakowa. W stosunkowo krótkim czasie pomiędzy badanymi okresami aż 10 gmin KOM (Czernichów, Drwina, Jerzmanowice-Przeginia, Koniusza, Krzeszowice - obszar wiejski, Niepołomice - obszar wiejski, Skała obszar wiejski, Skała - miasto, Wieliczka - miasto, Zielonki) przeszło z typu D (przewaga przyrostu migracyjnego nad ubytkiem naturalnym) do typu C (przewaga dodatniego przyrostu migracyjnego nad dodatnim przyrostem naturalnym). Przykładami mogą być gminy, takie jak: Koniusza, Zielonki, Zabierzów z bezpośredniego sąsiedztwa miasta stołecznego, czy położone dalej, jak: Jerzmanowice-Przeginia, Skała, Słomniki. Dzieje się tak na skutek napływu migrantów m.in. z terenu miasta Krakowa, który szczególnie silnie zaznacza się na terenie KOM-u. W jednostkach położonych na północ od obszaru metropolitalnego zmiany 
demograficzne wciąż kształtowane są przez ujemny przyrost naturalny, ujemne saldo migracji lub obydwa te procesy jednocześnie (Długosz, 2009).

Z opisanych powyżej powodów pomimo malejącej roli rolnictwa obszary wiejskie Małopolski cechują się dużym i rosnącym potencjałem demograficznym. Faktem jest, że województwo małopolskie zamieszkuje druga co do liczebności populacja wiejska w naszym kraju (po województwie mazowieckim), a tylko w czterech województwach (małopolskie, lubelskie, świętokrzyskie i podkarpackie) wskaźnik urbanizacji jest niższy od 50\%.
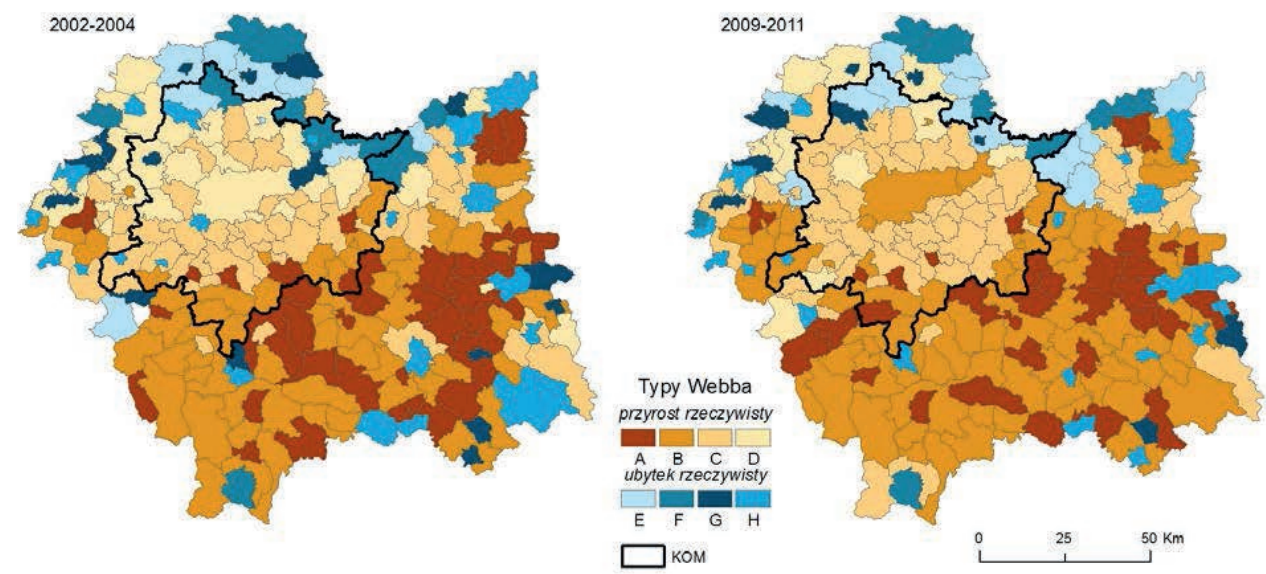

Ryc. 1. Typologia gmin województwa małopolskiego według metody Webba w latach 2002-2004 i 2009-2011

Źródło: opracowanie własne na podstawie Banku Danych Lokalnych GUS

Przeludnienie małopolskiej wsi oraz ukryte bezrobocie charakteryzujące gospodarstwa regionu nie są zjawiskami nowymi. Sytuacji tej nie poprawiły gwałtowne przemiany, jakim podlegało nasze państwo w XX wieku. Utworzone w okresie industrializacji pozarolne miejsca pracy nie doprowadziły do zmiany tego stanu. Schyłkowy okres gospodarki centralnie sterowanej, jak i transformacja ustrojowa pogłębiły niekorzystne zjawiska. W latach dziewięćdziesiątych ubiegłego wieku pojawił kolejny pomysł zmierzenia się z problemem - idea wielofunkcyjnego rozwoju wsi. Szczególny nacisk kładziono m.in. na rozwój agroturystyki jako naturalnego przedłużenia działalności rolniczej (Dorocki i in., 2012). Opracowane projekty i towarzyszące im niekiedy działania nie zmieniły jednak ogólnego obrazu wsi (Małopolski program..., 1997).

Na przeszkodzie gruntownym przemianom, jakim podlegały inne części kraju, stanęła poza wspomnianymi procesami decydującymi o dużej gęstości zaludnienia (ryc. 2) m.in. dominacja niewielkich gospodarstw chłopskich połączona ze znacznym rozdrobnieniem pól. Prowadzi to do ogromnych trudności w zakresie racjonalizacji struktury agrarnej choćby przez scalanie gruntów. To z kolei (w połączeniu z mało sprzyjającymi warunkami agroklimatycznymi większej części województwa) wpływa na niską efektywność ekonomiczną 
rolnictwa. Małopolska cechuje się najwyższą liczbą pracujących (w przeliczeniu na 100 ha Użytków Rolnych) i najniższą średnią powierzchnią gospodarstw indywidualnych (ryc. 3).
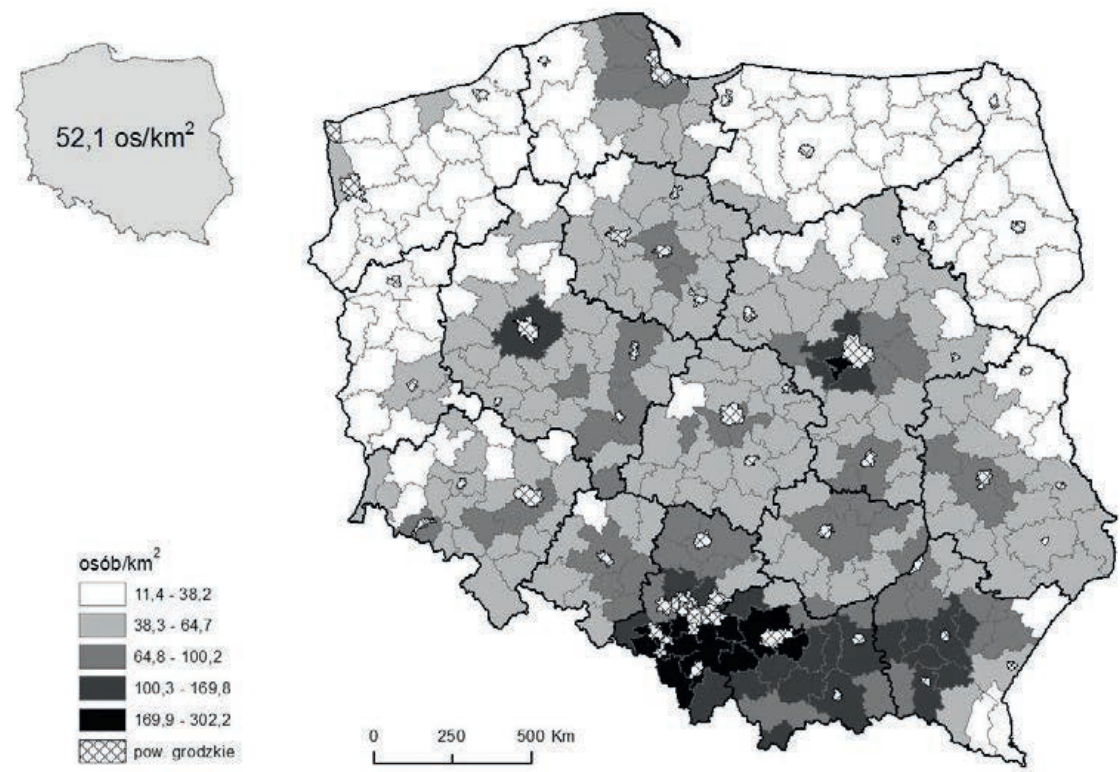

Ryc. 2. Gęstość zaludnienia obszarów wiejskich według powiatów w 2011 roku Źródło: opracowanie własne na podstawie Banku Danych Lokalnych (GUS 2012)

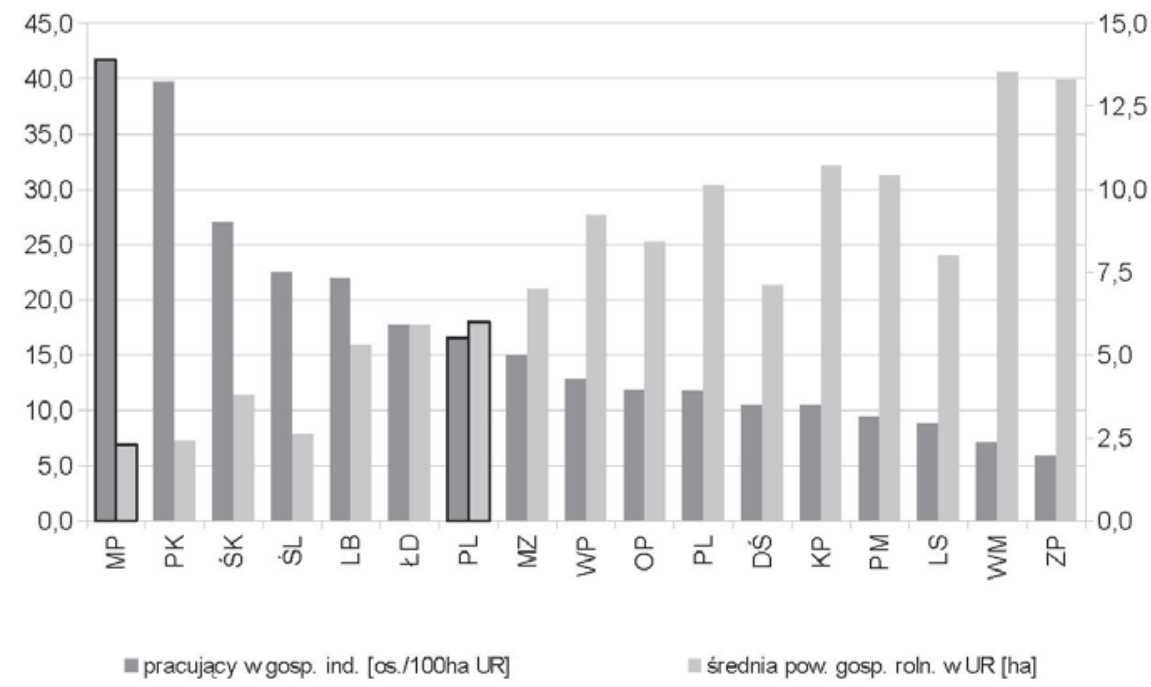

Ryc. 3. Pracujący w gospodarstwach indywidualnych i średnia wielkość gospodarstw indywidualnych w Polsce według województw w 2010 r.

Źródło: opracowanie własne na podstawie Powszechnego Spisu Rolnego 2010 GUS 
Wieś nie jest odizolowana od przemian zachodzących w naszym kraju. Ich nasilenie oraz kierunek bywają odmienne niż w miastach (szczególnie tych dużych). Można jednak wskazać na ogólnie malejącą rolę rolnictwa w życiu mieszkańców wsi zarówno jako sposobu życia, jak i źródła dóbr materialnych. Proces ten szczególnie rozpowszechnił w dwóch typach obszarów wiejskich: okolicach dużych miast i w najbardziej atrakcyjnych pod względem turystycznym regionach Małopolski. Z dużym prawdopodobieństwem można stwierdzić, że w dalszym ciągu te regiony będą podlegać szczególnie silnym zmianom. Na razie jednak wyniki badań BAEL (Badania Aktywności Ekonomicznej Ludności) prowadzonych przez GUS wskazują, że wskaźnik zatrudnienia na terenach wiejskich w Polsce maleje (ryc. 4). Dla województwa małopolskiego (jako całości) wskaźnik ten wyniósł 49,8\%.

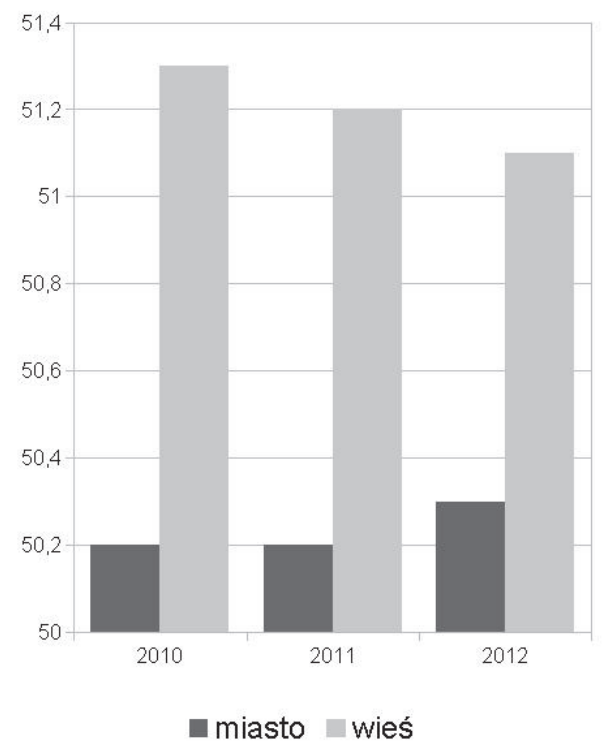

Ryc. 4. Wskaźnik zatrudnienia w Polsce III kw. (2010-2012)

Źródło: opracowanie na podstawie danych BAEL

Współczesne procesy serwicyzacji struktur gospodarczych powodują, że aktywność ekonomiczna ludności koncentruje się przede wszystkim w obszarach miejskich (Zioło, Kudełko, 2006). Dlatego wskaźniki aktywności zawodowej mieszkańców obszarów wiejskich należą do bardzo niskich (Domański, 2008). Na kartogramach przedstawiono wskaźniki aktywności ekonomicznej w sektorach pozarolniczych na obszarach wiejskich. Widać wyraźnie, że najniższe wartości wskaźników aktywności są charakterystyczne dla Krakowskiego Obszaru Metropolitalnego. Jest to wynikiem silnego oddziaływania Krakowa i jego miast satelitarnych w zakresie rynku pracy. Znaczny odsetek osób zamieszkujących na obszarach wiejskich KOM podejmuje pracę w Krakowie. Jako wyjątek należy przyjąć gminę wiejską Zabierzów, która m.in. ze względu na zlokalizowanie w jej granicach takich istotnych ośrodków pracy jak lotnisko w Balicach (Kraków Airport) czy Kraków Business Park (KBP) 
ma bardzo wysoki wskaźnik aktywności ekonomicznej. Należy przy tym zwrócić uwagę na szybkie tempo wzrostu aktywności w tej gminie, co jest związane przede wszystkim z rozbudową KBP, na terenie którego obecnie pracuje już kilka tysięcy osób. Rozbudowana baza ekonomiczna Krakowa wynika w dużej mierze z kumulacyjnych efektów aglomeracyjnych, stanowiąc podstawę samonapędzającego się wzrostu gospodarczego na tym obszarze, zdolności do tworzenia i akumulacji wiedzy oraz elastyczności w dostosowaniu do zmieniających się warunków gospodarczych w czasie postępującej globalizacji (Domański, 2007; 2008 Korenik, Szołek, 2004; Markowski, Marszał, 2007). W obszarach peryferyjnych, położonych z dala od dużych ośrodków miejskich wskaźnik aktywności ekonomicznej często jest wyższy ze względu na znaczny czas i koszt dojazdów do obszarów rdzeniowych województwa, co przekłada się na konieczność podejmowania pracy na miejscu. Dotyczy to przede wszystkim obszaru południowo-wschodniej części województwa.

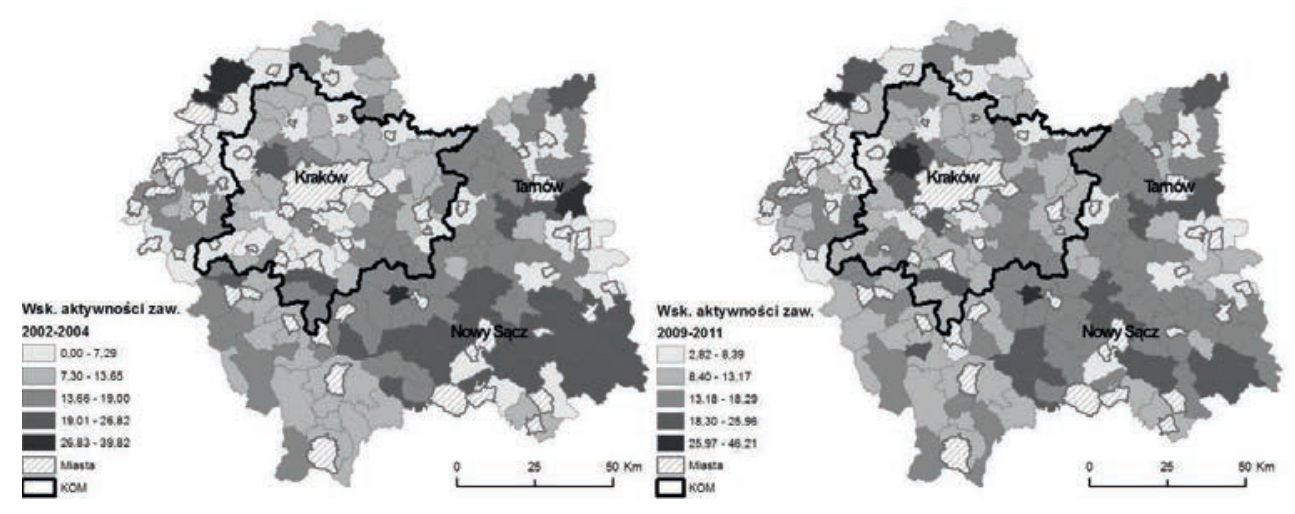

Ryc. 5. Aktywność ekonomiczna w gminach wiejskich województwa małopolskiego w latach 2002-2004 oraz 2009-2011

Źródło: opracowanie własne na postawie Banku Danych Lokalnych GUS

Przyjęty na potrzeby niniejszego opracowania wskaźnik opisujący poziom przedsiębiorczości mieszkańców terenów wiejskich Małopolski (ryc. 6) opiera się na liczbie podmiotów gospodarczych w rejestrze REGON w przeliczeniu na 100 mieszkańców. Widoczny jest wyższy poziom aktywności gospodarczej w pobliżu dużych miast (szczególnie obszar KOM) i w części zachodniej (powiat oświęcimski, wadowicki, olkuski). Bardzo wysokie wskaźniki przedsiębiorczości w powiecie wadowickim wynikają nie tylko z rozbudowanych usług, ale rozwoju przedsiębiorczości opierającej się na produkcji przemysłowej i rzemieślniczej. Szczególnie intensywnie rozwinęła się tu produkcja meblarska i obuwnicza. Bardzo niskie wartości wskaźnika przedsiębiorczości są charakterystyczne dla wschodniej części województwa. W największym stopniu dotyczy to obszaru położonego na północ i południe od Tarnowskiego Obszaru Miejskiego.

Niezbędnym elementem analizy przestrzennej wyjaśniającej relacje przestrzenne jest kwestia dostępności. Z punktu widzenia dostępności usług podstawową rolę w omawianym 
regionie pełnią takie ośrodki jak Kraków (będący miastem o funkcjach ponadregionalnych) oraz ośrodki subregionalne, do których zaliczyć należy Tarnów, Nowy Sącz i Nowy Targ. Dlatego przedmiotem naszej analizy stała się dostępność do tych właśnie miast. Z obszarów najbardziej peryferyjnych ta dostępność wynosi nawet ponad 90 minut. W praktyce zdecydowanie ogranicza to codzienne dojazdy do szkoły, pracy z tych terenów. Opisana we wcześniejszej analizie sytuacja gospodarcza obszaru województwa świadczy jednoznacznie o tym, że ośrodki subregionalne są zdecydowanie słabszymi miastami pod względem atrakcyjności dla dojeżdżających. Wynika z tego, że z perspektywy oceny szans poszczególnych regionów znacznie ważniejsza jest ocena dostępności do Krakowa niż pozostałych miast (Zioło, 2004).

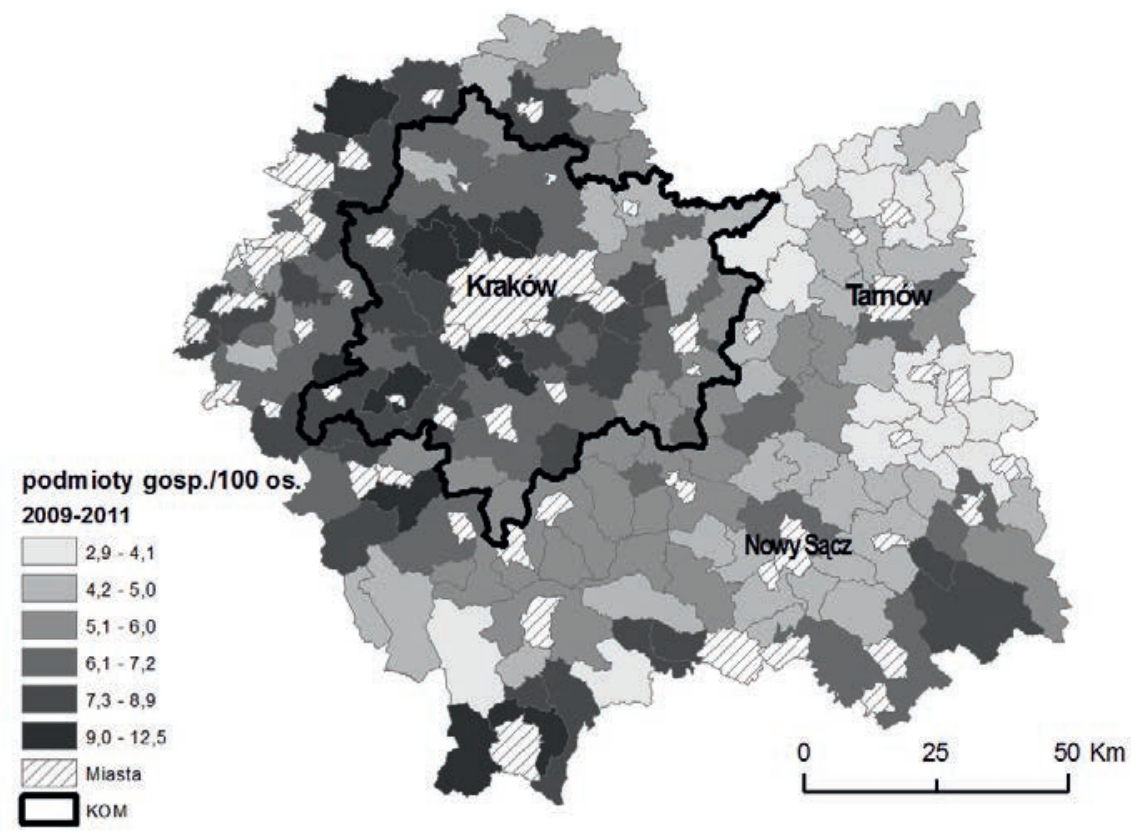

Ryc. 6. Pozarolnicze podmioty gospodarcze w rejestrze REGON w województwie małopolskim w latach 2009-2011

Źródło: opracowanie własne na podstawie Bank Danych Lokalnych GUS 2012

W przypadku obszaru województwa małopolskiego (ryc. 7) najlepszą dostępnością do Krakowa cechują się obszary położone wzdłuż głównych ciągów komunikacyjnych prowadzących do tego miasta. Szczególnie wzdłuż osi wschód-zachód wyznaczonej przez autostradę A4 dostępność obszarów do godziny jazdy do tego miasta sięga od zachodniej granicy województwa do obszaru podmiejskiego Tarnowa. Na obszarach położonych na północ od miasta dostępność jest wyraźnie mniejsza, co jest konsekwencją znacznie gorszej jakości dróg łączących te obszary z Krakowem. Jeszcze gorzej sytuacja przestawia się dla obszaru południowego. Widać wyraźnie, iż podgórski obszar Karpat wyraźnie negatywnie wpływa na dostępność tych obszarów. Wkrótce dostępność regionu północno-wschodniego 
i wschodniego powinna ulec zdecydowanej poprawie ze względu na nowo otwartą autostradę A4, która znacznie przyspieszy dojazd do Krakowa.

Zasięg dogodnej dostępności przestrzennej ośrodków subregionalnych jest podobny jak Krakowa. Sieć dróg wokół tych ośrodków jest jednak znacznie słabiej rozwinięta niż w przypadku Krakowa. Dobra dostępność tych miast jest zapewniona przede wszystkim z obszarów znajdujących się w bezpośrednim sąsiedztwie głównych dróg. Tereny położone pomiędzy obszarami bezpośredniego oddziaływania poszczególnych ośrodków cechują się wyraźnymi ograniczeniami w rozwoju funkcjonalnym będącymi konsekwencją słabej dostępności komunikacyjnej.

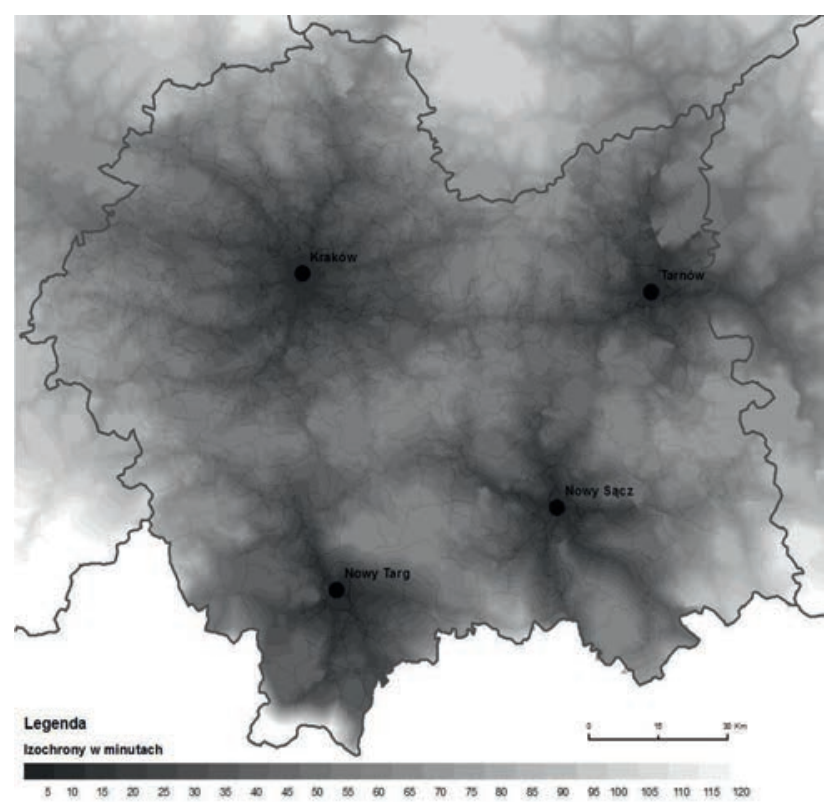

Ryc. 7. Dostępność drogowa wybranych miast województwa w 2012 roku

Źródło: opracowanie własne na podstawie sieci dróg południowej Polski (stan na 15.11.2012)

Peryferyjność obszarów wynikająca z bariery dostępności przestrzennej przekłada się na mniejsze szanse rozwoju zawodowego. Ma to zdecydowane odzwierciedlenie w dostępie do rynku pracy. Stopa bezrobocia na obszarach peryferyjnych ma zdecydowanie wyższe wartości (ryc. 8). Dotyczy to przede wszystkim obszarów położonych pomiędzy najważniejszymi ośrodkami aglomeracji, do których należą gminy powiatów limanowskiego, gorlickiego i dąbrowskiego.

Przedstawiony na rycinie 8 wskaźnik stopy bezrobocia dotyczył dwóch przekrojów czasu. W Polsce lata 2002-2004 były okresem charakteryzującym się największym bezrobociem. Od tego czasu do początku kryzysu światowego jesieni 2008 roku sytuacja na rynku pracy ulegała systematycznej poprawie. Dlatego też w okresie 2009-2011 wartości stopy bezrobocia były zdecydowanie niższe. Natomiast rozkład zjawiska w układzie przestrzennym nie uległ zasadniczym zmianom. 

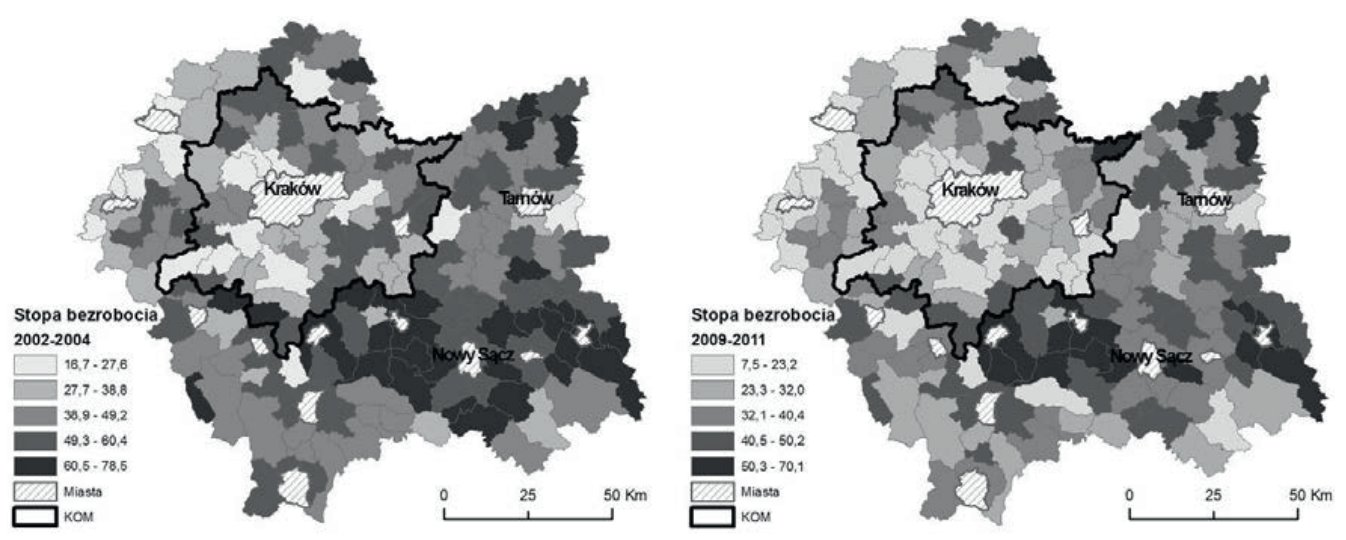

Ryc. 8. Stopa bezrobocia w województwie małopolskim w latach 2002-2004 oraz 2009-2011

Źródło: opracowanie własne na podstawie Banku Danych Lokalnych GUS

\section{Podsumowanie}

Współcześnie zachodzące procesy społeczno-gospodarcze prowadzą do pogłębienia zróżnicowania przestrzennego aktywności gospodarczej pomiędzy centrami wzrostu a obszarami peryferyjnymi. Wynika to głównie z postępujących procesów serwicyzacji gospodarki szczególnie w zakresie aktywizacji zasobów pracy. Usługi, szczególnie te wyższego rzędu, skupiają się w miastach, głównie dużych, co prowadzi do wzrostu ich znaczenia przy spadającej roli obszarów wiejskich. Dotyczy to przede wszystkim obszarów wiejskich położonych na terenach o niewystarczająco rozbudowanej infrastrukturze drogowej oraz sieci połączeń pasażerskich, która stanowi ograniczenie w zakresie w dostępności komunikacyjnej do i z tych regionów.

W przypadku województwa małopolskiego główną barierą w aktywizacji zawodowej wiejskich obszarów peryferyjnych są słabo rozwinięte pod względem gospodarczym miasta na tych terenach. Nawet największe subregionalne ośrodki miejskie jak Tarnów i Nowy Sącz, które stanowią najważniejsze ośrodki centralne we wschodniej części województwa, nie posiadają obecnie wystarczającego potencjału gospodarczego, aby w większym stopniu oddziaływać na gospodarkę swoich subregionów. Małe ośrodki miejskie wykazują silne tendencje do odpływu ludności - szczególnie te zlokalizowane w obszarach peryferyjnych oraz miasta, w których dominowała funkcja przemysłowa. Obszary wiejskie, szczególnie te położone w południowej i wschodniej części województwa, charakteryzują się natomiast przewagą napływu ludności i dodatnimi wartościami przyrostu naturalnego. Procesy ludnościowe zachodzące obecnie w miastach i gminach Małopolski utrwalają sytuację na lokalnych rynkach pracy. 


\section{WNIOSKI KOŃCOWE}

Polityka transportowa stanowi jeden z najważniejszych czynników kształtujących aktywność gospodarczą terenów wiejskich. Słaby rozwój sieci transportowej oraz anachroniczny transport publiczny nie sprzyjają obszarom położonym peryferyjnie. Słaba aktywizacja i trudna sytuacja demograficzna terenów wiejskich i małych miast będą się prawdopodobnie pogłębiać. Potrwa to tak długo, jak peryferyjność będzie się objawiać w postaci braku powszechnej dostępności najbardziej atrakcyjnych ośrodków miejskich.

\section{Literatura}

Borowiec, M. (2008). Obszary wiejskie objęte semiurbanizacją w woj. małopolskim. W: T. Markowski, Z. Strzelecki (red.), Obszary urbanizacji i semiurbanizacji wsi polskiej a możliwości ich rozwoju w ramach PROW 2007-2013. Studia KPZK PAN, 90-122.

Długosz, Z. (2009). Population Ageing and its Predictions for 2030 in the Małopolskie Voivodship compared to Poland and Europe. Moravian Geographical Reports, 1, 17, 2-18.

Domański, B. (2007). Metropolitan Areas as 'Switching Points' in the Networks of Relationships. W: T. Marszał, W. Zmitrowicz (red.), Metropolies and Metropolitan Areas - Structures, Functions and Role. Studia Regionalia, 20, 23-31.

Domański, B. (2008). Rozwój polskich metropolii a regiony peryferyjne - bezpowrotna separacja czy współzależność rozwoju? Studia KPZK PAN, 120, 135-146.

Dorocki, S., Szymańska, A., Zdon-Korzeniowska, M. (2012). Polskie gospodarstwa agroturystyczne jako przedsiębiorstwa rodzinne. W: Ł. Sułkowski (red.), Firmy rodzinne - wspótczesne wyzwania przedsiębiorczości rodzinnej. Determinanty rozwoju. Łódź: Społeczna Akademia Nauk, 45-60.

European Commission (2011). Agricultural Policy Perspectives Briefs, 1.

Farrington, J. (2007). The New Narrative of Accessibility: Its Potential Contribution to Discourses in (Transport) Geography. Journal of Transport Geography, 15, 319-330.

Farrington, J., Farrington, C. (2005). Rural Accessibility, Social Inclusion and Social Justice. Journal of Transport Geography, 13, 1-12.

Górz, B., Uliszak, R. (2009). Przestrzeń wiejska Małopolski i jej zmiany pod wpływem funduszy europejskich. W: I. Jażewicz (red.), Współczesne problemy przemian strukturalnych przestrzeni geograficznej. Słupsk: Akademia Pomorska w Słupsku, 233-248.

Guzik, R. (2003). Przestrzenna dostępność szkolnictwa ponadpodstawowego. Kraków: Instytut Geografii i Gospodarki Przestrzennej UJ.

Guzik, R., Wiedermann, K. (2012). Powiązania w zakresie dojazdów do pracy. W: R. Guzik (red.), Czynniki i ograniczenia rozwoju miast województwa pomorskiego $w$ świetle relacji przestrzennych i dostępności komunikacyjnej. Gdańsk: Urząd Marszałkowski Województwa Pomorskiego, 67-100.

Keeling, D. (2009). Transportation Geography: Local Challenges, Global Contexts. Progress in Human Geography, 33 (4), 516-526.

Komornicki, T., Śleszyński, P., Rosik, P., Pomianowski, W. (2010). Dostępność przestrzenna jako przesłanka kształtowania polskiej polityki transportowej. Biuletyn KPZK PAN, 241. 
Korenik, S., Szołek, K. (red.) (2004). Konkurencyjność i potencjał rozwoju polskich metropolii - szanse i bariery. Biuletyn KPZK PAN, 214.

Kurek, S. (2007). Typologia procesu starzenia się ludności miast i gmin Polski na tle jego demograficznych uwarunkowań. Przeglad Geograficzny, 79(1), 133-156.

Kurek, S., Rachwał T. (2011). Development of Entrepreneurship in Ageing Populations of the European Union. Procedia - Social and Behavioral Sciences, 19 (2011), 397-405.

Kwiatek-Sołtys, A. (2011). Barriers and Factors of Growth of Small Towns of Poland. Elsevier, Procedia - Social and Behavioral Sciences, 19, 363-370.

Małopolski program rozwoju wsi i rolnictwa (1997). Bielsko-Biała-Kielce-Kraków-Krosno-Nowy Sącz-Przemyśl-Rzeszów-Tarnobrzeg-Tarnów: Małopolska Rada Regionalna.

Markowski, T., Marszał, T. (2007). Metropolitan Areas of Poland - Chalanges and Policy Recommendations. W: T. Marszał, W. Zmitrowicz (red.), Metropolies and Metropolitan Areas - Structures, Functions and Role. Studia Regionalica, 20, 9-22.

Moseley, M. (1979). Accessibility: The Rural Challenge. London: Methuen.

Nutley, S. (1983). Transport Policy Appraisal and Personal Accessibility in Rural Wales. Norwich: Geo Books.

Nutley, S. (1998). Rural Areas: The Accessibility Problem. W: B. Hoyle, R. Knowles (eds.), Modern Transport Geography. Chichester: Wiley, 185-215.

Pacione, M. (1989). Access to Urban Services: The Case of Secondary Schools in Glasgow. Scottish Geographical Magazine, 105, 12-18.

Raport z wyników województwa małopolskiego. Powszechny Spis Rolny 2010 (2011). Kraków: Urząd Statystyczny w Krakowie.

Taylor, Z. (1998). Możliwości poprawy dostępności usług w obszarach wiejskich. Przegląd Geograficzny, 70, 1-2.

Wilkin J., Nurzyńska I. (red.) (2012). Polska wieś 2012. Raport o stanie wsi. Warszawa: Wydawnictwo Naukowe Scholar.

Zioło, Z. (2004). Procesy i modele kształtowania krajowych układów regionalnych. W: Z. Mikołajewicz (red.), Procesy i kierunki przemian gospodarczych w Polsce w okresie transformacji. Zeszyty Naukowe Uniwersytetu Opolskiego. Ekonomia, 28, 143-163.

Zioło, Z., Kudełko, J. (2006). Funkcje małych miast w przestrzeni rolniczej. W: E. Rydz (red.). Rola małych miast w rozwoju obszarów wiejskich. Studia Obszarów Wiejskich, 11. Warszawa: Komisja Obszarów Wiejskich PTG, Zespół Badań Obszarów Wiejskich Instytutu Geografii i PZ PAN, 39-58.

Marcin Semczuk, mgr, Uniwersytet Pedagogiczny w Krakowie, Instytut Geografii, Zakład Przedsiębiorczości i Gospodarki Przestrzennej.

Absolwent studiów z zakresu geografii społeczno-ekonomicznej Uniwersytetu Pedagogicznego w Krakowie. Doktorant w Instytucie Geografii na tej uczelni. Jego zainteresowania badawcze skupiają się wokół problematyki regionów i procesów regionalizacji społeczno-gospodarczej.

Marcin Semczuk, graduated from Pedagogical University of Cracow, MA degree in Geography. $\mathrm{PhD}$ student at the Pedagogical University of Cracow, the Institute of Geography. His research interests focus on regional problems and processes of socio-economic regionalization.

Radosław Uliszak, dr, Uniwersytet Pedagogiczny w Krakowie, Instytut Geografii, Zakład Geografii Społeczno-Ekonomicznej.

Absolwent studiów z zakresu geografii Uniwersytetu Pedagogicznego w Krakowie, doktor nauk geograficznych w dyscyplinie geografia (Wydział Geograficzno-Biologiczny, Uniwersytet Pedagogiczny 
w Krakowie). Adiunkt w Instytucie Geografii na tej uczelni. Jego zainteresowania badawcze skupiają się wokół problematyki geografii terenów wiejskich na obszarze Polski, Unii Europejskiej i Indii. Rezultatem jego zainteresowań dydaktyką geografii jest autorstwo dwóch podręczników szkolnych do nauczania geografii w gimnazjum i szkołach ponadgimnazjalnych (współautor Krzysztof Wiedermann).

Radosław Uliszak, graduated from the Pedagogical University of Cracow, MA degree in Geography, $\mathrm{PhD}$ in Geography (the Pedagogical University of Cracow, the Institute of Geography). Senior Lecturer at the Pedagogical University of Cracow, the Institute of Geography. His research interests focus on geography of rural areas in Poland, European Union and India. The result of his interest in the field of teaching geography is the authorship of two geography school textbooks for middle school and high school (co-author Krzysztof Wiedermann).

Krzysztof Wiedermann, dr, Uniwersytet Pedagogiczny w Krakowie, Instytut Geografii, Zakład Geografii Społeczno-Ekonomicznej.

Absolwent studiów z zakresu geografii społeczno-ekonomicznej Uniwersytetu Jagiellońskiego. W 2006 roku obronił doktorat w Instytucie Geografii na Uniwersytecie Jagiellońskim. Obecnie adiunkt w Instytucie Geografii Uniwersytetu Pedagogicznego w Krakowie. Główny nurt prowadzonych przez niego badań dotyczy rozwoju lokalnego i regionalnego. Opracował koncepcję wyliczania efektów mnożnikowych wynikających z lokalizacji nowych egzogenicznych działalności produkcyjnych. Obecnie prowadzi także prace badawcze $\mathrm{z}$ zakresu rozwoju miast zarówno w aspekcie funkcjonalnym, jak i morfologicznym. Jest także współautorem podręcznika z geografii do szkół ponadgimnazjalnych (wspólnie z Radosławem Uliszakiem).

Krzysztof Wiedermann, graduate at the Jagiellonian University, MA degree in Socio-economic Geography. In 2006 he obtained his $\mathrm{PhD}$ degree at the Institute of Geography at the Jagiellonian University. Senior Lecturer at the Pedagogical University of Cracow, the Institute of Geography. The main research fields concern local and regional development. He developed the concept of calculating the multiplier effects arising from the location of new exogenous production activities. He is currently carrying out the research in the field of urban development, both in terms of functional and morphological changes. He is also a co-author of a geography school handbook for high schools (with Radosław Uliszak).

adres/address: Uniwersytet Pedagogiczny w Krakowie, Instytut Geografii,

ul. Podchorążych 2, 30-084 Kraków, Polska

e-mail:semczuk@interia.eu (Marcin Semczuk),

ulira@up.krakow.pl (Radosław Uliszak),

k.wiedermann@up.krakow.pl (Krzysztof Wiedermann) 